\title{
Limits to growth and respiration of bacterioplankton in the Gulf of Mexico
}

\author{
L. R. Pomeroy, Joan E. Sheldon, Wade M. Sheldon Jr, Francesc Peters
}

Institute of Ecology, University of Georgia, Athens, Georgia 30602-2202, USA

\begin{abstract}
We compared microbial community respiration and related parameters in the Gulf of Mexico in January and June 1993. Microbial community respiratory rates in the upper mixed layer varied from $<0.03 \mu \mathrm{M} \mathrm{O}_{2} \mathrm{~h}^{-1}$ in the central Gulf in January to $1.4 \mu \mathrm{M} \mathrm{O}_{2} \mathrm{~h}^{-1}$ in the Mississippi River plume in June. Although higher respiratory rates were found in June than in January, no significant differences were found in bacterial numbers or mean cell volume. Dissolved free amino acid concentrations were an order of magnitude higher in June, but there was little difference in concentrations of phosphate or monosaccharides between January and June. Enrichment experiments in June showed phosphate to be the primary limiting factor for bacterial production and microbial community respiration and organic carbon substrates to be a secondary limiting factor. Respiratory rate and bacterial secondary production increased when phosphate was added to water samples. Ammonium, iron and other trace metals, vitamins and chelators had no effect. Glucose was utilized only when supplemented with phosphate. Turnover time of bacterial biomass in June, based on counts, sizes, and production data, was 7 to $30 \mathrm{~h}$, with the shortest times at oligotrophic stations. The observed rates of bacterial respiration and production imply the utilization of multiple sources of organic and recycled inorganic nutrients in a complex and inefficient food web.
\end{abstract}

KEY WORDS: Bacterioplankton production - Community respiration - Gulf of Mexico - Limiting factors . Phosphate

\section{INTRODUCTION}

Inputs of Mississippi River water and water from the Caribbean Sea result in a wide range of environments for planktonic communities in the Gulf of Mexico, from oligotrophy to eutrophy. The Gulf is dominated by the loop current, a geostrophically driven current associated with the Florida Current, which periodically releases large eddies that can entrain continental shelf water into the central Gulf (Vukovich 1988). Surveys by ships, satellite imagery, and modeling have shown the Gulf of Mexico to have essentially summer and winter seasons, with the latter producing more phytoplankton because mixing by frontal storms lowers the thermocline and introduces nutrients into the mixed layer (El-Sayed et al. 1972, Walsh et al. 1989). With the exception of the Campeche and Florida Strait regions, seasonal variations in phosphate concentration of an order of magnitude occur (Churgin \& Halminski 1974). While concentrations of phosphate tend to be higher in winter, Loop Current activity can inject shelf water containing higher concentrations of nutrients into an otherwise oligotrophic region at any time (Walker et al. 1993). Seasonal ranges in temperature are 5 to $8^{\circ} \mathrm{C}$ for any region of the Gulf, and may approach $20^{\circ} \mathrm{C}$ near shore. Temperature minima in open water of the north and east Gulf are around $19^{\circ} \mathrm{C}$ and maxima in the southern portions of the Gulf and inner Florida continental shelf approach $30^{\circ} \mathrm{C}$ (Churgin \& Halminski 1974).

In such a subtropical regime, one might expect primary production to be limited principally by the availability of inorganic nutrients and heterotrophic microbial processes to be limited by primary production. Evidence for the former seems good. To investigate the latter in both winter and summer conditions, we undertook a broad survey of microbial community respiration and bacterial processes in the upper mixed layer. During 2 cruises aboard RV 'Pelican' in January and June 1993 (utilizing the same stations), we measured microbial community respiratory rates, chlorophyll fluorescence, soluble reactive phosphate, dissolved 
free amino acids (DFAA), and dissolved monosaccharides. During the June cruise we also measured bacterial secondary production and conducted enrichment experiments. Bacterial numbers were counted at selected stations on both cruises, and bacterial biomass was estimated. This permits us to make comparisons with seasonal changes in microbial processes reported from other latitudes.

\section{METHODS}

Near-surface salinity, water temperature, and chlorophyll fluorescence were recorded under way by an on-board system on RV 'Pelican', and those parameters also were recorded during sampling casts with the ship's SeaBird SBE-9 CTD. On both cruises, Stn 14 was centered in the plume of the Mississippi River in darkness with the aid of continuous under-way recording of humate fluorescence using a Turner Designs fluorometer at an excitation wavelength of $360 \mathrm{~nm}$ and reading fluorescence at $>510 \mathrm{~nm}$. Fluorometer output was fed through an analog-digital converter to a computer programmed to compile and graphically present the fluorescence data in real time. This provided less ambiguous detection of the river plume than did chlorophyll or salinity. Water samples were collected with a rosette of Niskin samplers closed with silicone tubing.

Dissolved amino acids, monosaccharides, and phosphate. Subsamples (3 per station) from the Niskin samplers for later analysis of DFAA were filtered through $0.2 \mu \mathrm{m}$ Anotec $^{\oplus}$ filter cartridges into fired glass vials using a new plastic syringe for each station. For each subsample, a new filter was used and $<20 \mathrm{ml}$ was passed through it in order to minimize the effects of cell disruption (Fuhrman 1985). The first $10 \mathrm{ml}$ passed through each new filter were discarded as a filter rinse, and then $<10 \mathrm{ml}$ was collected. Samples were stored at $-20^{\circ} \mathrm{C}$ for later analysis by high performance liquid chromatography according to the general precolumn derivatization procedure developed by Lindroth \& Mopper (1979) and Mopper \& Lindroth (1982). We followed the specific procedure of Henrichs \& Williams (1985) except that samples were thawed at $4^{\circ} \mathrm{C}, 2 \mathrm{ml}$ subsamples were derivatized, and $300 \mu \mathrm{l}$ was injected. Derivatized primary amino acids were separated in a $250 \times 4.6 \mathrm{~mm}$ cartridge-style column (Alltech) packed with Spherisorb ODS-1 $5 \mu$ (Phase Separation) and detected using a Kratos FS970 Spectrofluoromonitor. The amino acids quantified were: aspartic acid, glutamic acid, serine, histidine + threonine + glycine (co-eluted), alanine, tyrosine, arginine, methionine, valine, phenylalanine, isoleucine, leucine, and lysine.
Unfiltered water samples also were frozen in acidwashed, fired vials for later analyses. Dissolved monosaccharides were measured using the MBTH method (Johnson et al. 1981). A standard curve was prepared using glucose, and the concentrations are reported as glucose equivalents. Additionally, phosphate was measured by the method of Murphy \& Riley (1962) after the reduction of arsenate (Johnson 1971).

Bacterial secondary production. During the June cruise, bacterial secondary production was calculated by measuring incorporation of ${ }^{3} \mathrm{H}$-leucine into protein (Kirchman et al. 1985) and converting leucine uptake to bacterial protein production (Simon \& Azam 1989). Triplicate sets of $10 \mathrm{ml}$ seawater samples were pulsed with $10 \mathrm{nM}$ leucine $\left(1 \mu \mathrm{Ci} \mathrm{L}-\left[3,4,5-{ }^{3} \mathrm{H}(\mathrm{N})\right]\right.$-leucine, $157 \mathrm{Ci} \mathrm{mmol}{ }^{-1}$, and $9.36 \mathrm{nM}$ unlabeled L-leucine) for $1 \mathrm{~h}$ at in situ temperature, and protein was extracted using $5 \%$ trichloroacetic acid at $95^{\circ} \mathrm{C}$ for $30 \mathrm{~min}$. Precipitated protein was then filtered, and the amount of ${ }^{3} \mathrm{H}$-leucine in protein was measured by liquid scintillation counting (Pomeroy et al. 1994). At Stns 3, 9, and 17, samples were pulsed with 3 different concentrations of leucine $(0.32,10$, and $30 \mathrm{nM})$ to examine uptake kinetics. Maximal uptake velocities of added leucine $\left(V_{\max }\right)$ were estimated from Wright-Hobbie plots (Wright \& Hobbie 1966, Logan \& Fleury 1993).

Leucine uptake velocity was converted to protein production according to Simon \& Azam (1989), except that where they assumed minimal natural extracellular leucine, we used a method to correct for extracellular as well as intracellular dilution. We began by assuming that leucine is incorporated into protein without isotope discrimination from a constant-sized intracellular pool supplied by intra- and extracellular sources. This incorporation rate, then, would be equal to the sum of the rates of supply of leucine to the pool from all sources. When uptake of external leucine is maximized $\left(V_{\max }\right)$, we assume that intracellular supply pathways are completely suppressed. Several studies support this assumption (see van Looij \& Riemann 1993). Under these conditions, the rate of incorporation of leucine into protein equals $V_{\max }$. Intracellular dilution is the ratio of the actual incorporation rate of all leucine to the measured incorporation rate of added leucine under subsaturating conditions $\left(V_{\text {added }}\right)$; therefore, dilution can be estimated as $V_{\max } / V_{\text {added }}$. This relationship was also used by van Looij \& Riemann (1993). We calculated dilution for $10 \mathrm{nM}$ of added leucine at Stns 3, 9, and 17 and applied the mean of those dilutions to the leucine uptake rates of the remaining stations.

Bacterial numbers and sizes. At selected stations, seawater samples were fixed with $0.5 \%$ alkaline Lugol's and $5 \%$ borate-buffered formalin and stored at $4^{\circ} \mathrm{C}$. Subsamples were stained with acridine orange 
and filtered onto $0.2 \mu \mathrm{m}$ polycarbonate membranes (Poretics). Bacteria were counted by epifluorescence microscopy (Hobbie et al. 1977). Bacteria were also measured using a calibrated ocular micrometer and separated into 5 size classes; mean cell volume (MCV) for each sample was then calculated based on the frequency of cells in each class, assuming bacteria were cocci or rods with hemispherical ends (Fry 1988). Bacterial biovolumes were calculated as the product of bacterial abundance and MCV measurements.

Respiratory rates and enrichments. Respiratory rates were measured on multiple replicate $125 \mathrm{ml}$ water samples incubated for $12 \mathrm{~h}$ at in situ temperature in the dark, using the precision Winkler method as described by Pomeroy et al. (1994). At Stns 2, 5, 8, 13, and 18 on the June cruise, some bottles were enriched with nutrient combinations, and oxygen utilization was measured after a $12 \mathrm{~h}$ incubation. At Stns 8, 13, and 18, leucine incorporation and bacterial size and numbers were also measured after enrichment and incubation. Enrichment treatments were adapted from Brand's BWM phytoplankton culture medium (Brand 1986). Final concentrations were: $10^{-5} \mathrm{M} \mathrm{NH}_{4}^{+}(\mathrm{N}) ; 10^{-5} \mathrm{M}$ $\mathrm{H}_{2} \mathrm{PO}_{4}{ }^{-}(\mathrm{P}) ; 10^{-5} \mathrm{M}$ EDTA $+10^{-6} \mathrm{M}$ Fe-EDTA $+10^{-7} \mathrm{M}$ $\mathrm{Zn}^{2+}+10^{-7} \mathrm{M} \mathrm{Mn}^{2+}+10^{-8} \mathrm{M} \mathrm{Co}^{2+}+10^{-8} \mathrm{M}^{2}$ vitamin $\mathrm{B}_{12}$ $+10^{-7} \mathrm{M}$ thiamine $+10^{-9} \mathrm{M}$ biotin $(\mathrm{M}) ; 1 \mathrm{mg} \mathrm{l}^{-1}$ glucose (G); the combinations $\mathrm{N}+\mathrm{P}+\mathrm{M}$ and $\mathrm{N}+\mathrm{P}+$ $\mathrm{M}+\mathrm{G}$; and unenriched controls. The glucose-only treatment was not used on Stn 2 .

\section{RESULTS}

Two cruises on RV 'Pelican' occupied as nearly as possible identical stations in the Gulf of Mexico in January and June 1993 (Fig. 1). The stations cover a range of conditions, from deep, oligotrophic water in the central Gulf to coastal waters on the Florida continental shelf and the Mississippi River plume west of Southwest Pass. In order to cover this range in the time available, samples were taken only from the upper mixed layer, usually at a depth of $10 \mathrm{~m}$ unless CTD observations showed a shallower mixed layer, as, for example, at the station in the Mississippi River plume. During the June cruise, the central Gulf of Mexico was dominated by a large eddy, $300 \mathrm{~km}$ in diameter, which had separated from the Loop Current (Walker et al. 1993).

Chlorophyll fluorescence, from both the CTD and the under-way sampling system, in June was 1 to $8 \times$ higher at individual stations than in January and was significantly different by paired $t$-test $(\mathrm{p}=0.0001)$. However, no consistent difference in mixed layer depth was evident between the 2 cruises. Reactive phosphate concentrations in the Mississippi River plume were $0.9 \mu \mathrm{M}$ in June and $1.66 \mu \mathrm{M}$ in January.

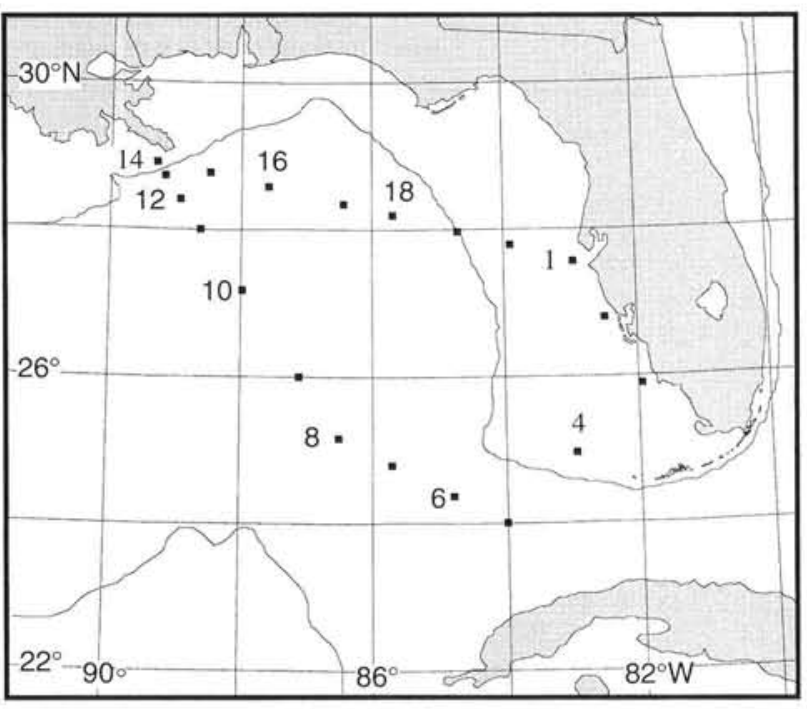

Fig. 1. Locations of the stations in the Gulf of Mexico occupied in both January and June 1993 by RV 'Pelican'. The $200 \mathrm{~m}$ isobath is delineated by a continuous line

Except for the Mississippi plume, reactive phosphate concentrations throughout our cruise track were mostly near our detection limit of $0.04 \mu \mathrm{M}$, with a range of $<0.04$ to 0.14 during both cruises. We could not detect a significant difference between the January and June phosphate concentrations. Dissolved monosaccharides tended to be higher in June, but were at most double the January concentrations (Table 1). The differences were too small to be statistically significant.

Bacterial numbers and biomass were similar in January and June (Table 2). Moreover, there was no clear distinction in bacterial numbers between waters of the continental shelf, continental slope, or the deep, central Gulf. All samples which were fixed immediately (i.e. without incubation) were dominated by small cocci $(0.2$ to $0.4 \times 0.2 \mu \mathrm{m})$, and both numbers and sizes of bacteria were typical of oligotrophic, oceanic systems. Bacterial numbers at the Mississippi plume station and the inner continental shelf station off Tampa Bay were an order of magnitude higher than elsewhere. The Mississippi River plume is a special situation that we exclude from our generalizations about the Gulf of Mexico.

The median microbial community respiratory rate in January approached our lower limit of resolution, which is around $0.03 \mu \mathrm{M} \mathrm{O}_{2} \mathrm{~h}^{-1}$, with 9 January stations below resolution. The June median respiratory rate was $0.15 \mu \mathrm{M} \mathrm{O}_{2} \mathrm{~h}^{-1}$, with values tailing off toward higher rates (Fig. 2). Respiratory rates were lower in January with the exception of Stn 5 in the Florida Strait and Stn 17 on the northeast Gulf continental slope, at 
Table 1. Dissolved free leucine $(\mathrm{nM})$, total dissolved free amino acids (DFAA, $\mathrm{nM}$ ) and total monosaccharides $(\mu \mathrm{M}$ glucose equivalents) in the Gulf of Mexico surface waters in January and June 1993

\begin{tabular}{|c|c|c|c|c|c|c|c|c|}
\hline Stn & Location & $\begin{array}{c}\text { Total } \\
\text { depth (m) }\end{array}$ & Leucine & $\begin{array}{c}\text { January } \\
\text { Total DFAA }\end{array}$ & Monosac. & Leucine & $\begin{array}{c}\text { June } \\
\text { Total DFAA }\end{array}$ & Monosac. \\
\hline 1 & $27^{\circ} 23^{\prime} \mathrm{N}, 82^{\circ} 55^{\prime} \mathrm{W}$ & 17 & 0.7 & 29. & 1.9 & - & - & - \\
\hline 2 & $26^{\circ} 37^{\prime} \mathrm{N}, 82^{\circ} 30^{\prime} \mathrm{W}$ & 20 & 1.2 & 22. & - & 31 & 968 & 3.3 \\
\hline 3 & $25^{\circ} 47^{\prime} \mathrm{N}, 82^{\circ} 04^{\prime} \mathrm{W}$ & 20 & 0.5 & 20 & 1.9 & - & - & - \\
\hline 4 & $24^{\circ} 59^{r} \mathrm{~N}, 83^{\circ} 02^{\prime} \mathrm{W}$ & 52 & 2.3 & 57 & 4.4 & - & - & - \\
\hline 5 & $24^{\circ} 00^{\prime} \mathrm{N}, 84^{\circ} 52^{\prime} \mathrm{W}$ & 2000 & 1.6 & 45 & - & 14 & 518 & 7.3 \\
\hline 6 & $24^{\circ} 24^{\prime} \mathrm{N}, 84^{\circ} 52^{\prime} \mathrm{W}$ & 3100 & 1.1 & 30 & 2.7 & - & - & - \\
\hline 7 & $24^{\circ} 48^{\prime} \mathrm{N}, 85^{\circ} 47^{\prime} \mathrm{W}$ & 3100 & 0.8 & 17 & 0.7 & - & - & - \\
\hline 8 & $25^{\circ} 13^{\prime} \mathrm{N}, 86^{\circ} 36^{\prime} \mathrm{W}$ & 3225 & 1.0 & 34 & 0.5 & 20 & 695 & 2.8 \\
\hline 9 & $26^{\circ} 00^{\prime} \mathrm{N}, 87^{\circ} 19^{\prime} \mathrm{W}$ & 3100 & 1.1 & 30 & 0.7 & - & - & - \\
\hline 10 & $26^{\circ} 48^{\prime} \mathrm{N}, 87^{\circ} 40^{\prime} \mathrm{W}$ & 2400 & 0.7 & 21 & 1.2 & & & \\
\hline 11 & $27^{\circ} 38^{\prime} \mathrm{N}, 88^{\circ} 41^{\prime} \mathrm{W}$ & 1500 & $<0.4$ & 12 & 2.5 & - & - & - \\
\hline 12 & $28^{\circ} 20^{\prime} \mathrm{N}, 89^{\circ} 19^{\prime} \mathrm{W}$ & 950 & 1.4 & 32 & 2.6 & - & - & - \\
\hline 13 & $28^{\circ} 34^{\prime} \mathrm{N}, 89^{\circ} 29^{\prime} \mathrm{W}$ & 550 & 1.3 & 28 & 1.1 & 26 & 965 & 2.3 \\
\hline 14 & $28^{\circ} 43^{\prime} \mathrm{N}, 89^{\circ} 27^{\prime} \mathrm{W}$ & 115 & 16.2 & 442 & 0.8 & 20 & 695 & 0.8 \\
\hline 15 & $28^{\circ} 36^{\prime} \mathrm{N}, 88^{\circ} 42^{\prime} \mathrm{W}$ & 500 & 1.8 & 53 & 0.6 & - & - & - \\
\hline 16 & $28^{\circ} 25^{\prime} \mathrm{N}, 87^{\circ} 44^{\prime} \mathrm{W}$ & 2050 & 3.0 & 68 & 1.4 & - & - & - \\
\hline 17 & $28^{\circ} 13^{\prime} \mathrm{N}, 86^{\circ} 45^{\prime} \mathrm{W}$ & 750 & 1.3 & 27 & 4.0 & - & - & - \\
\hline 18 & $28^{\circ} 03^{\prime} \mathrm{N}, 85^{\circ} 47^{\prime} \mathrm{W}$ & 800 & 1.3 & 26 & - & 17 & 584 & 1.5 \\
\hline 19 & $27^{\circ} 50^{\prime} \mathrm{N}, 84^{\circ} 50^{\prime} \mathrm{W}$ & 230 & $<0.9$ & $<30$ & 1.0 & - & - & - \\
\hline 20 & $27^{\circ} 39^{\prime} \mathrm{N}, 83^{\circ} 53^{\prime} \mathrm{W}$ & 50 & 0.6 & 19 & 4.3 & - & - & - \\
\hline
\end{tabular}

which the January rates were approximately twice those found in June. The difference was most pronounced in the Mississippi River plume, but at many stations June respiratory rates were 5 to 10 times those in January (Table 3).

DFAA concentrations were strikingly different on the 2 cruises (Table 1). With small variances, the June values exceeded those in January everywhere (except the Mississippi River plume) by more than an order of magnitude. Other than respiratory rates, this is the largest difference we found between conditions in January and June.

We measured bacterial secondary production only on the June cruise (Table 4). Calculated dilution fac-

Table 2. Bacterial numbers $\left(10^{5}\right.$ bacteria $\left.\mathrm{ml}^{-1}\right)$ in the upper mixed layer of the Gulf of Mexico in January and June 1993

\begin{tabular}{|rcc|}
\hline Stn & January & June \\
\hline 1 & - & 27.9 \\
4 & - & 6.7 \\
5 & 3.8 & 4.2 \\
6 & 2.1 & - \\
7 & - & 3.8 \\
8 & - & 5.5 \\
9 & 7.4 & 4.0 \\
10 & 2.7 & - \\
13 & 8.4 & 6.6 \\
14 & 12.0 & 30 \\
17 & - & 5.3 \\
18 & - & 5.6 \\
\hline
\end{tabular}

tors (means and $95 \%$ confidence limits) were: Stn 3 , 8.1 ( 5.1 to 19 ); $\operatorname{Stn} 9,10.9$ (6.6 to 29.5 ); $\operatorname{Stn} 17,6.1$ (4.5 to 9.5 ). Confidence limits are asymmetrical around the point estimates because confidence limits were originally obtained for $1 / V_{\max }$ and then inverted. An overall dilution estimate of 8 was used in the calculation of bacterial protein production for all stations. These data permit us to place limits on bacterial assimilation efficiencies (growth yields) in June. For purposes of estimating bacterial efficiency, we compared 3 assumptions about the relative contribution to total respiration by various classes of autotrophs and heterotrophs. As a first approach, we assumed that all of the measured microbial community respiration was that of bacterial

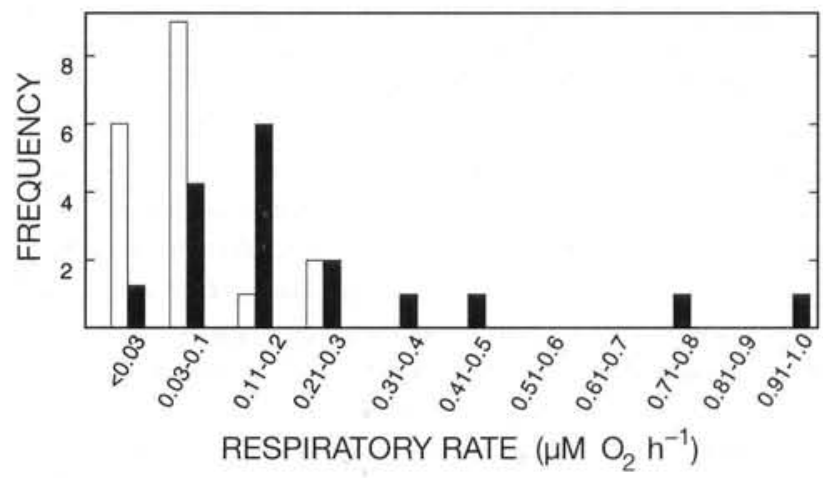

Fig. 2. Frequency distributions of microbial community respiratory rates in the Gulf of Mexico in 1993. Open bars: January; solid bars: June 
Table 3. Microbial community respiratory rates in the upper mixed layer of the Gulf of Mexico in January and June 1993. Positions and total depths are reported in Table 1. CL: confidence limits

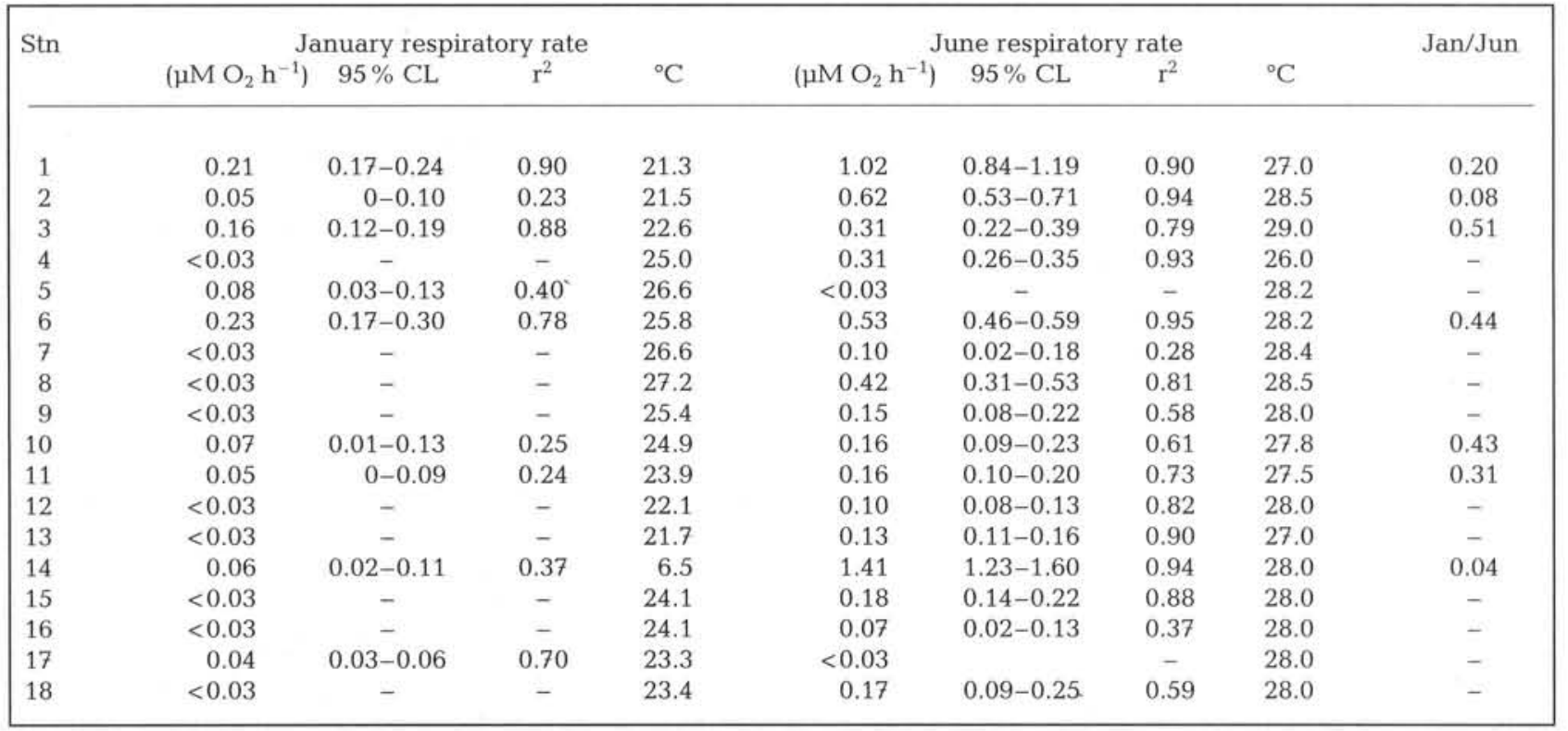

heterotrophs. This is not correct, but estimates of bacterial biomass and phytoplankton respiratory rates in other subtropical waters suggest that phytoplankton respiration is often a small fraction of total microbial respiration (Laws et al. 1987, Fuhrman et al. 1989, Grande et al. 1989). For a second approach, we assume that half the observed respiration is from heterotrophic bacteria, the remainder being that of protozoans and autotrophic phytoplankton and bacteria. For a third approach, we developed a linear regression of phytoplankton respiratory rates against chlorophyll a based on the data of Laws et al. (1987) and Grande et al. (1989). In the range 0 to $1 \mu \mathrm{g}$ chlorophyll $1^{-1}$, respiration $=0.05 \mu \mathrm{M} \mathrm{O}_{2} \mathrm{~h}^{-1} \mu \mathrm{g}^{-1}$ chlorophyll $\left(\mathrm{r}^{2}=0.94 ; \mathrm{n}=5\right)$.

Table 4. Bacterial secondary production, microbial community respiration, and estimated bacterial assimilation efficiency (growth yield) in the upper mixed layer of the Gulf of Mexico, June 1993. Bacterial turnover time is reported for those stations where biovolume was measured. See text for details of the calculations. RQ was assumed to equal 1 in these calculations

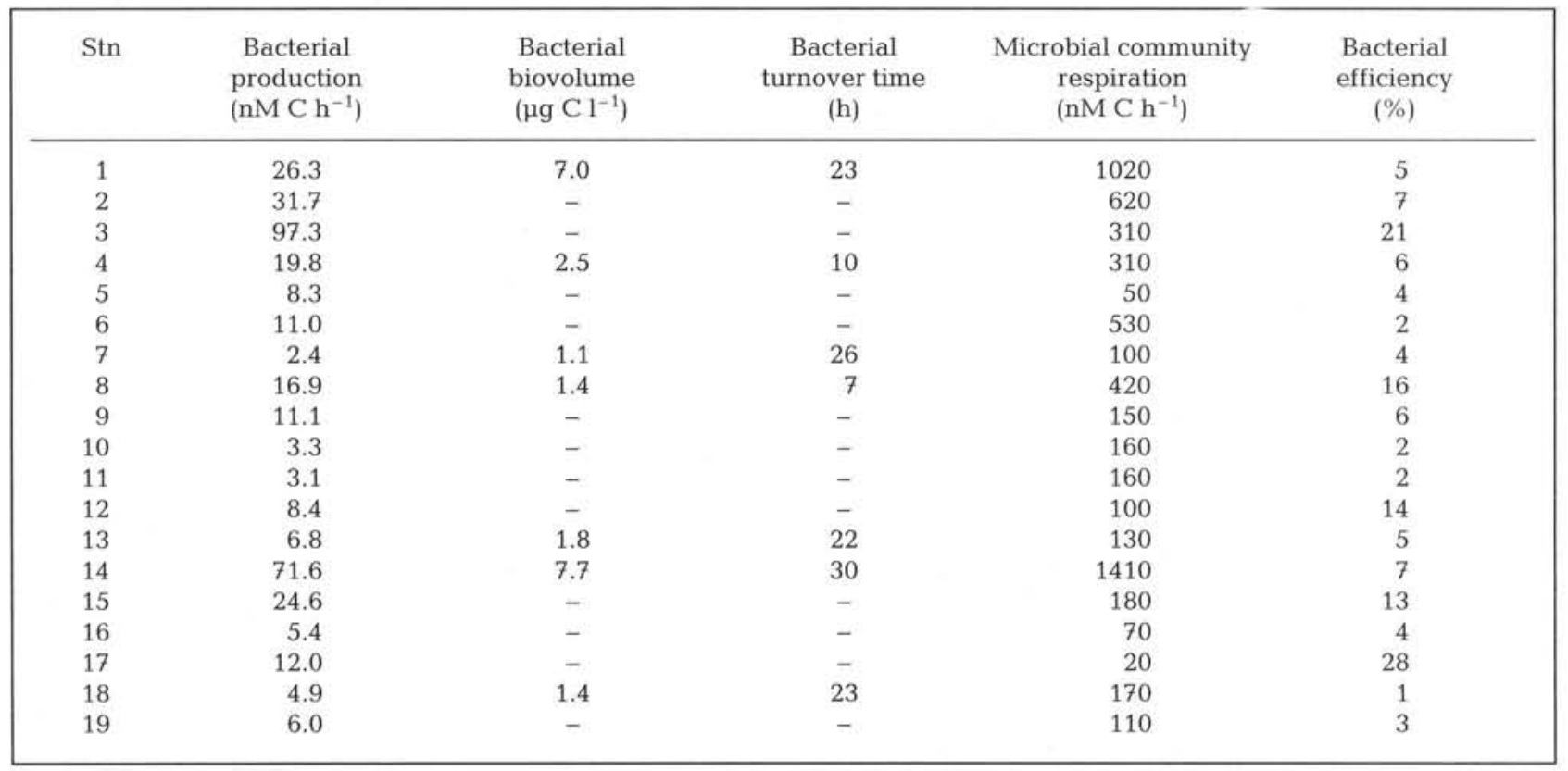


This regression was applied to the approximate estimates of chlorophyll from the ship's fluorometers to give a crude approximation of phytoplankton respiration. We then subtracted the estimated phytoplankton respiration from microbial community respiration and assumed that $90 \%$ of the remainder was bacterial. The 3 sets of assumptions produced very similar estimates of bacterial assimilation efficiency. June bacterial assimilation efficiencies are mostly low, ranging from 1 to $28 \%$; Table 4 uses assumption 1, so the reader can multiply that by any chosen factor. A similar range is reported by Biddanda et al. (1994) whose observations are limited to the Louisiana shelf, one of the most productive regions of the Gulf. As Biddanda et al. and others (e.g. Griffith et al. 1990) have pointed out, bacterial assimilation efficiency seems to be lower in oligotrophic environments.

In June, enrichment experiments with natural microbial communities from the upper mixed layer were carried out at 5 stations: Stn 2 on the west-coast Florida shelf, Stn 5 in the Florida Strait, Stn 8 in the central Gulf, Stn 13 on the upper continental slope, near the shelf break to the south of the Mississippi River delta and Stn 18 on the lower continental slope in the northeastern Gulf. At all 5 stations, the primary limiting factor was phosphorus, and a secondary limiting factor was organic carbon substrates. Added glucose was utilized only when phosphorus was also supplemented (Table 5). At 3 of the 5 stations, the combined addition of phosphorus, ammonium, iron and other trace metals, vitamins, and chelators showed a small but significant increase over the effect of phosphorus alone on microbial oxygen utilization. The greatest increases in microbial oxygen utilization at all stations were with the complete enrichment, which included both phosphorus and glucose.

Changes in leucine incorporation and oxygen utilization in the enrichment experiments were greater than changes in bacterial numbers or biovolume. Numbers of bacteria at most doubled in the controls and in enrichments with phosphorus alone. Compared to the controls, bacteria increased by a factor of 2 to 4 in enrichments that included both phosphorus and glucose. During $12 \mathrm{~h}$ incubations, bacterial biovolume increased by factors of 4 to 13 in the P + G enrichments. Relative to the controls, leucine uptake in the P + G enrichments increased by a factor of 5 at Stns 8 and 18 but by a factor of 91 at Stn 13. Oxygen utilization increased less: $5 \times$ at $\operatorname{Stn} 8,14 \times$ at $\operatorname{Stn} 13$, and $8 \times$ at Stn 18 . The differential changes in bacterial secondary production and oxygen utilization are also reflected in changes in bacterial growth yield. Initial growth yields in the controls were 1 to $3 \%$, if one assumed that $100 \%$ of measured respiration is bacterial or 2 to $6 \%$ if $50 \%$ of respiration is bacterial. Because leucine assimilation increased faster than changes in respiratory rate, growth yield tended to rise in the enrichments, but since these are transient, shift-up conditions, yield is inconsistent.

\section{DISCUSSION}

A major winter-summer difference in the Gulf of Mexico in 1993 was microbial community respiration, with significantly higher rates occurring in early summer. This is consistent with seasonal comparisons in other parts of the ocean. The annual maximum of microbial community respiratory rates frequently coincides with the annual temperature maximum, while microbial community respiratory rates at the annual temperature minimum approach detection limits (Griffith et al. 1990, Pomeroy et al. 1991, Pomeroy \& Wiebe 1993, Griffith \& Pomeroy in press). Temperatures approaching annual minima appear to result in an increase in the limiting concentrations of dissolved organic substrates required by bacteria for growth, even in the subtropics (Wiebe et al. 1993, Nedwell \& Rutter 1994). Conditions in the Gulf of Mexico during our cruises were not entirely consistent with historical data (El-Sayed et al. 1972, Churgin \& Halminski 1974, El-Sayed \& Turner 1977, Walsh et al. 1989). Walsh et al. report that stability returns rapidly after mixing events in the winter in the Gulf of Mexico, and since our cruise occurred in fair weather, that may explain why we found no difference in the depth of the mixed layer between January and June. Contrary to expectations, chlorophyll a fluorescence was higher in June than in January.

A second major summer-winter difference in the Gulf of Mexico in 1993 was the presence of much higher concentrations of DFAA in June. These are both a nitrogen source and a carbon source for bacteria (Wheeler \& Kirchman 1986). Therefore, one potential explanation for the higher bacterial respiratory rates might be the presence of a large source of amino acids in June throughout the Gulf of Mexico. However, the cause of the accumulation is not evident and is contrary to the more usual finding that dissolved amino acids are utilized very rapidly by active communities of free heterotrophic bacteria (Hagström et al. 1984, Fuhrman 1987). One possible explanation for the accumulation of DFAAs comes out of our enrichment experiments.

The enrichment experiments, in 5 different regions of the Gulf of Mexico, uniformly point to reactive phosphate as the primary factor limiting bacterial secondary production. Chin-Leo \& Benner (1992) found that organic carbon was the principal limiting factor for bacterial production in the Mississippi River plume in 
Table 5. Effect of nutrient enrichments on bacterial numbers, bacterial biovolume, bacterial incorporation of ${ }^{3} \mathrm{H}$-leucine (Leu. inc.), and microbial community respiration. P: phosphorus; N: ammonium nitrogen; M: metals, vitamins, and EDTA; G: glucose. Within each station, means with shared letters are not significantly different (Tukey-Kramer procedure, alpha $=0.05$ ). LCL, UCL: lower and upper confidence limits

\begin{tabular}{|c|c|c|c|c|c|c|c|c|}
\hline Stn & $\begin{array}{l}\text { Incubation } \\
\text { time (h) }\end{array}$ & Treatment & $\begin{array}{l}\text { Bact. no. } \\
\left(10^{9} 1^{-1}\right)\end{array}$ & $\begin{array}{c}\text { Biovolume } \\
\left(10^{6}{\left.\mu \mathrm{m}^{3} 1^{-1}\right)}^{-1}\right.\end{array}$ & \multicolumn{2}{|c|}{ Leu. inc. $\left(\mathrm{nM} \mathrm{h}^{-1}\right)$} & \multicolumn{2}{|c|}{$\begin{array}{c}\Delta \mathrm{O}_{2}(\mu \mathrm{M} \text { from } t=0) \\
\text { Mean }(95 \% \text { LCL-UCL })\end{array}$} \\
\hline \multirow[t]{8}{*}{8} & 0.0 & Control & 0.55 & 4 & 0.016 & $(0.015-0.018)$ & & \\
\hline & 13.3 & Control & 0.52 & 37 & $0.128^{\mathrm{a}}$ & $(0.028-0.229)$ & $5.4^{\mathrm{a}}$ & $(4.4-6.4)$ \\
\hline & 13.3 & G & 0.58 & 25 & $0.099^{a}$ & $(0.086-0.112)$ & $4.9^{\mathrm{a}}$ & $(4.5-5.4)$ \\
\hline & 13.3 & $\mathrm{~N}$ & 0.57 & 21 & $0.096^{\mathrm{a}}$ & $(0.084-0.107)$ & $4.6^{\mathrm{a}}$ & $(4.2-5.0)$ \\
\hline & 13.3 & M & 0.43 & 19 & $0.083^{\mathrm{a}}$ & $(0.072-0.094)$ & $4.3^{\mathrm{a}}$ & $(3.4-5.2)$ \\
\hline & 13.3 & $\mathrm{P}$ & 1.11 & 135 & $0.481^{b}$ & $(0.364-0.598)$ & $14.2^{\mathrm{b}}$ & $(13.3-15.0)$ \\
\hline & 13.3 & NPM & 1.33 & 93 & $0.498^{\mathrm{b}}$ & $(0.402-0.593)$ & $15.5^{\mathrm{b}}$ & $(14.4-16.7)$ \\
\hline & 13.3 & NPMG & 1.81 & 155 & $0.719^{c}$ & $(0.669-0.768)$ & $25.7^{c}$ & $(24.7-26.7)$ \\
\hline \multirow[t]{8}{*}{13} & 0.0 & Control & 0.66 & 5 & 0.007 & $(0.001-0.012)$ & & \\
\hline & 12.5 & Control & 0.95 & 33 & $0.011^{\mathrm{a}}$ & $(0.010-0.012)$ & $1.6^{\mathrm{a}}$ & $(1.3-2.0)$ \\
\hline & 12.5 & G & 0.91 & 34 & $0.006^{\mathrm{a}}$ & $(0.005-0.006)$ & $0.9^{\mathrm{a}}$ & $(0.3-1.6)$ \\
\hline & 12.5 & $\mathrm{~N}$ & 0.80 & 50 & $0.005^{\mathrm{a}}$ & $(0.004-0.005)$ & $1.0^{\mathrm{a}}$ & $(0.4-1.6)$ \\
\hline & 12.5 & M & 0.80 & 25 & $0.009^{\mathrm{a}}$ & $(0.008-0.010)$ & $1.0^{\mathrm{a}}$ & $(0.4-1.6)$ \\
\hline & 12.5 & $\mathrm{P}$ & 0.99 & 173 & $0.629^{c}$ & $(0.518-0.741)$ & $7.9^{\mathrm{b}}$ & $(7.0-8.7)$ \\
\hline & 12.5 & NPM & 0.87 & 110 & $0.436^{\mathrm{b}}$ & $(0.372-0.500)$ & $8.2^{\mathrm{b}}$ & $(4.9-11.5)$ \\
\hline & 12.5 & NPMG & 2.26 & 436 & $0.998^{\mathrm{d}}$ & $(0.781-1.22)$ & $22.9^{c}$ & $(22.4-23.3)$ \\
\hline \multirow[t]{8}{*}{18} & 0.0 & Control & 0.56 & 4 & 0.005 & $(0.004-0.005)$ & & \\
\hline & 12.3 & Control & 0.69 & 67 & $0.180^{\mathrm{b}}$ & $(0.156-0.204)$ & $2.1^{\mathrm{a}}$ & $(1.6-2.6)$ \\
\hline & 12.3 & $\mathrm{G}$ & 0.64 & 61 & $0.146^{a, b}$ & $(0.124-0.169)$ & $2.6^{a}$ & $(2.1-3.2)$ \\
\hline & 12.3 & $\mathrm{~N}$ & 0.68 & 47 & $0.085^{\mathrm{a}, \mathrm{b}}$ & $(0.068-0.103)$ & $2.0^{\mathrm{a}}$ & $(1.7-2.4)$ \\
\hline & 12.3 & M & 0.65 & 53 & $0.078^{\mathrm{a}}$ & $(0.068-0.087)$ & $2.2^{\mathrm{a}}$ & $(1.7-2.6)$ \\
\hline & 12.3 & $\mathrm{P}$ & 0.73 & 114 & $0.490^{c}$ & $(0.376-0.605)$ & $5.5^{\mathrm{b}}$ & $(5.1-5.9)$ \\
\hline & 12.3 & NPM & 0.72 & 99 & $0.556^{c}$ & $(0.398-0.714)$ & $7.3^{c}$ & $(6.9-7.8)$ \\
\hline & 12.3 & NPMG & 1.53 & 316 & $0.846^{\mathrm{d}}$ & $(0.728-0.963)$ & $17.2^{\mathrm{d}}$ & $(16.5-17.9)$ \\
\hline \multirow[t]{7}{*}{2} & 0.0 & Control & & & & & & \\
\hline & 12.3 & Control & & & & & $7.6^{\mathrm{a}}$ & $(6.9-8.3)$ \\
\hline & 12.3 & N & & & & & $10.2^{\mathrm{a}}$ & $(7.1-13.3)$ \\
\hline & 12.3 & M & & & & & $7.6^{\mathrm{a}}$ & $(7.1-8.2)$ \\
\hline & 12.3 & $\mathrm{P}$ & & & & & $19.3^{\mathrm{b}}$ & $(18.9-19.7)$ \\
\hline & 12.3 & NPM & & & & & $20.8^{b}$ & $(20.3-21.3)$ \\
\hline & 12.3 & NPMG & & & & & $26.4^{c}$ & $(25.8-26.9)$ \\
\hline \multirow[t]{8}{*}{5} & 0.0 & Control & & & & & & \\
\hline & 12.2 & Control & & & & & $0.6^{\mathrm{a}}$ & $(-1.1-2.2)$ \\
\hline & 12.2 & G & & & & & $3.8^{\mathrm{b}}$ & $(2.2-5.3)$ \\
\hline & 12.2 & $\mathrm{~N}$ & & & & & $3.6^{\mathrm{b}}$ & $(3.0-4.3)$ \\
\hline & 12.2 & M & & & & & $4.9^{\mathrm{b}}$ & $(4.4-5.5)$ \\
\hline & 12.2 & $\mathrm{P}$ & & & & & $10.5^{c}$ & $(9.9-11.2)$ \\
\hline & 12.2 & NPM & & & & & $14.4^{\mathrm{d}}$ & $(13.1-15.7)$ \\
\hline & 12.2 & NPMG & & & & & $23.0^{\mathrm{e}}$ & $(22.2-23.8)$ \\
\hline
\end{tabular}

July-August 1991, while nitrogen and to a lesser extent phosphorus was limiting in February 1991. Ammerman et al. (1994), Cotner et al. (1994) and Peele et al. (1994) found both phytoplankton and bacteria to be limited by phosphorus in the Sargasso Sea during summer and producing alkaline phosphatase to hydrolyze organic phosphorus compounds. Krom et al. (1991) reported that primary production and possibly bacterial production is limited by phosphorus in the eastern Mediterranean. Our enrichment experiments suggest that phosphorus limitation of bacterioplankton production was widespread in the Gulf of Mexico in June 1993. While our June Stn 13 is in water of slightly reduced salinity near the Mississippi delta, and Stn 2 is on the inner Florida shelf, Stns 5, 8, and 18 are in highsalinity, high-temperature water typical of the relatively oligotrophic central Gulf of Mexico.

Growth limitation by inorganic nutrients, especially phosphorus, has been studied largely in phytoplankton, although there have been clear indications that bacteria often compete with phytoplankton for ammonium (Wheeler \& Kirchman 1986) and may be nitrogen-limited (Kirchman 1994). Our observation that phosphorus limits the ability of heterotrophic bacteria to assimilate glucose raises questions about how limiting factors may act sequentially on heterotrophs. In 
this instance, limitation of growth by phosphorus may have reduced bacterial utilization of the dissolved free amino acids, allowing them to accumulate temporarily to unusually high concentrations. Such an explanation is at least consistent with the results of the enrichment experiments.

This is not to say that bacteria were inactive in the Gulf of Mexico in June. Turnover time of bacterial biomass in the Gulf of Mexico, estimated from biovolume and production data, is 7 to $30 \mathrm{~h}$, which is even shorter than it is in the Sargasso Sea (Fuhrman et al. 1989). Although some pelagic bacterioplankton are always dividing, most of them appear to be in a starvation mode of reduced size and reduced metabolic activity. However, they can respond to enrichment within a few hours (Amy et al. 1983, Hagström et al. 1984). Kjelleberg et al. (1993) found that Vibrio strain S14 in culture made the reverse change, from large, active cells to small, stress-resistant ones, only as a result of organic carbon starvation and not from limiting concentrations of phosphorus or nitrogen. If this is a valid generalization, it raises questions about the sequence of events leading to the presence of extensive communities of small, stress-resistant bacteria in the oligotrophic ocean, if phosphorus is indeed frequently limiting to the growth of aerobic, heterotrophic bacterioplankton.

Although bacterial respiratory rates became high in June, bacterial assimilation efficiency was low. We measured total microbial respiratory rates, not bacterial respiratory rates, but any of our 3 assumptions about the fraction of respiration owing to heterotrophic bacteria result in estimates of bacterial assimilation efficiency well below the widely assumed value of $50 \%$ in most instances (Table 4 ). Only by assuming that bacteria are responsible for $<5 \%$ of total microbial respiration would we conclude that bacterial assimilation efficiency was $50 \%$ or greater in over half the observations. Pace et al. (1984) estimated that $60 \%$ of microbial respiration was by heterotrophic bacteria in their most oligotrophic model, while Moloney \& Field (1991) estimated that $15 \%$ of microbial respiration was by heterotrophic bacteria in their oligotrophic model. This reflects the uncertainty in our knowledge and possibly the wide range of possibilities. Our measurements and those of others (e.g. Griffith et al. 1990) suggest that the assimilation efficiency of natural communities of bacteria is highly variable, much more so than numbers or biomass. This is further reason to be wary of generalizations about assimilation efficiency, no matter how badly they are needed for modeling and other calculations.

Seasonal changes in phytoplankton photosynthesis in the Gulf of Mexico are reported to be smaller than the seasonal changes we found in microbial community respiratory rates (El-Sayed et al. 1972). Bacterial production rates plus microbial community respiratory rates in June 1993 exceed published rates of photosynthesis (El-Sayed et al. 1972), so the Gulf of Mexico appears likely to be a net heterotrophic system in summer. The observation that microbial respiratory rates may equal and sometimes exceed net rates of phytoplankton production in the upper mixed layer of the ocean is strong evidence that bacteria and other elements of the microbial food web are major movers of energy and materials in the ocean. While this is already widely appreciated, it may still be overlooked in evaluations of rates of planktonic processes, including limitation of growth of microheterotrophs by inorganic nutrients. Our enrichment experiments show that bacteria in a variety of situations in the Gulf of Mexico in June were limited in their utilization of organic carbon sources by the availability of inorganic phosphorus and were users, not regenerators, of phosphate. Studies in fresh water have shown that bacteria have much higher affinity for phosphate than do typical freshwater phytoplankton, and bacteria do compete effectively for the available phosphate (Currie \& Kalff 1984a). However, in freshwater systems, bacteria were thought to be limited by the supply of organic carbon (Currie \& Kalff 1984b). In the Gulf of Mexico, at least in June 1993, where the dominant photoautotrophs include Synechococcus, Prochlorococcus, and small eukaryotic organisms not very different in size from the bacteria, the balance seems to shift to phosphate limitation for heterotrophic bacteria. This adds emphasis to the realization that the microbial food web in natural waters is not just a microscopic version of the food web of macroorganisms but has distinctive features that result from the abilities and limitations of bacteria.

Fuhrman et al. (1989) point out that very short turnover times of bacterial biomass in the oligotrophic ocean, which we also found to be characteristic of the Gulf of Mexico, imply rates of growth that cannot be supported by accepted rates of production of dissolved organic matter (DOM) by phytoplankton. This paradox of the bacterioplankton may be explained in several ways. First, autotrophic bacterioplankton and other very small autotrophs that are responsible for much of the photosynthesis in oligotrophic oceans and mediterranean seas are turned over rapidly by flagellate grazers, and this is a potentially major source of DOM for heterotrophic bacteria in addition to direct release of DOM by phytoplankton (Hagström et al. 1988). Second, in tropical and subtropical waters, the degradation of refractory DOM to more labile compounds by ultraviolet radiation in near-surface water may provide a subsidy for bacteria above the DOM supplied directly or indirectly from photosynthesis (Mopper et al. 1991, Miller 1994). Further, Pakulski et al. (1995) 
have found as much as half of the oxygen utilization at intermediate salinities in the Mississippi River plume is by nitrifying bacteria. Finally, bacterial assimilation efficiency in oligotrophic waters where $\mathrm{C}, \mathrm{N}$, or P limit growth is lower than has been generally recognized. Thus, several factors may at times combine to result in high rates of bacterial respiration in the sea.

Acknowledgements. This work was supported by National Science Foundation grant OCE9115673. We thank Steve Rabalais, Capt. Chris Reiffe, and the crew of the Louisiana Universities Marine Consortium vessel 'Pelican' for their assistance and cooperation in this work. L.R.P. thanks John A. Downing and Arthur S. Brooks for stimulating discussions that led to the enrichment experiments. We thank R. Benner, B. A. Biddanda, J. D. Pakulski, and R. E. Turner for helpful comments on a draft of the manuscript.

\section{LITERATURE CITED}

Ammerman, J. W., Bentzen, E., Peele, E. R., Cotner, J. B. Jr, Jeffrey, W. H. (1994). Phosphorus cycling at the Bermuda time-series station: an overview. EOS 75: 100

Amy, P. S., Pauling, C., Morita, R. Y. (1983). Recovery from nutrient starvation by a marine Vibrio sp. Appl. environ. Microbiol. 45: 1685-1690

Biddanda, B. A., Opsahl, S., Benner, R. (1994). Plankton respiration and carbon flux through bacterioplankton on the Louisiana shelf. Limnol. Oceanogr. 39: 1259-1275

Brand, L. E. (1986). Nutrition and culture of autotrophic ultraplankton and picoplankton. In: Platt, T., Li, W. K. W. (eds.) Photosynthetic picoplankton. Can. Bull. Fish. Aquat. Sci. 214: $205-233$

Chin-Leo, G., Benner, R. (1992). Enhanced bacterioplankton production and respiration at intermediate salinities in the Mississippi River plume. Mar. Ecol. Prog. Ser, 87: 87-103

Churgin, J., Halminski, S. J. (1974). Temperature, salinity, oxygen, and phosphate in waters off United States. Gulf of Mexico, Vol. 2, Key to oceanographic records documentation. National Oceanographic Data Center, Washington, DC

Cotner, J. B., Peele, E. R., Ammerman, J. W., Bentzen, E. (1994). Phosphorus-limited plankton growth in the Sargasso Sea (BATS) and implications for the pelagic food web. EOS 75: 75

Currie, J. D., Kalff, J. (1984a). The relative importance of bacterioplankton and phytoplankton in phosphorus uptake in freshwater. Limnol. Oceanogr. 29: 311-321

Currie, J. D., Kalff, J. (1984b). Can bacteria outcompete phytoplankton for phosphrous? Microb. Ecol. 10: 205-216

El-Sayed, S. Z., Sackett, W. M., Jeffrey, L. M., Fredericks, A. D., Saunders, R. P., Conger, P. S., Fryxell, G. A., Steidinger, K. A., Earle, S. A. (1972). Chemistry, primary productivity, and benthic algae of the Gulf of Mexico. Folio 22. Serial atlas of the marine environment. In: Bushnell, V. C. (ed.) American Geographical Society, New York, p. 1-29

El-Sayed, S. Z., Turner, J. T. (1977). Productivity of the Antarctic and tropical/subtropical regions: a comparative study. In: Dunbar, M. J. (ed.) Polar Oceans. Arctic Institute of North America, Calgary, p. 463-503

Fry, J. C. (1988). Determination of biomass. In: Austin, B. (ed.) Methods in aquatic bacteriology. John Wiley \& Sons, London
Fuhrman, J. A. (1985). Biological considerations in the measurement of dissolved free amino acids in seawater and implications for chemical and biological studies. Mar. Ecol. Prog. Ser. 25: 13-21

Fuhrman, J. A. (1987). Close coupling between release and uptake of dissolved free amino acids in seawater studied by an isotope dilution approach. Mar. Ecol. Prog. Ser. 37: $45-52$

Fuhrman, J. A., Sleeter, T. D., Carlson, C. A., Proctor, L. M. (1989). Dominance of bacterial biomass in the Sargasso Sea and its ecological implications. Mar. Ecol. Prog. Ser. 57: $207-217$

Grande, K. D., Williams, P. J. L., Marra, J., Purdie, D. A., Heinmann, K., Eppley, R. W., Bender, M. L. (1989). Primary production in the North Pacific gyre: a comparison of rates determined by the ${ }^{14} \mathrm{C}, \mathrm{O}_{2}$ concentration, and ${ }^{18} \mathrm{O}$ methods. Deep Sea Res. 36: 1621-1634

Griffith, P. C., Douglas, D. J., Wainright, S. C. (1990). Metabolic activity of size-fractionated microbial plankton in estuarine, nearshore, and continental shelf waters of Georgia. Mar. Ecol. Prog. Ser. 59: 263-270

Griffith, P. C., Pomeroy, L. R. (in press). Seasonal and spatial variations in microbial community respiration on the southeastern U.S. continental shelf. Cont. Shelf Res.

Hagström, A.., Ammerman, J. W., Henrichs, S., Azam, F. (1984). Bacterioplankton growth in seawater: II. Organic matter utilization during steady-state growth in seawater cultures. Mar. Ecol. Prog. Ser. 18: 41-48

Hagström, Å., Azam, F., Andersson, A., Wikner, J., Rassoulzadegan, F. (1988). Microbial loop in an oligotrophic pelagic marine ecosystem: possible roles of cyanobacteria and nanoflagellates in the organic fluxes. Mar. Ecol. Prog. Ser, 49: 171-178

Henrichs, S. M., Williams, P. M. (1985). Dissolved and particulate amino acids and carbohydrates in the sea surface microlayer. Mar. Chem. 17: 141-163

Hobbie, J. E., Daley, R. J., Jasper, S. (1977). Use of nuclepore filters for counting bacteria by fluorescence microscopy. Appl. environ. Microbiol. 49; 1225-1228

Johnson, D. L. (1971). Simultaneous determination of arsenate and phosphate in natural waters. Environ. Sci. Technol. 5: 411-414

Johnson, K. M., Burney, C. M., Sieburth, J. M. (1981). Doubling the production and precision of the MBTH spectrophotometric assay for dissolved carbohydrates in seawater. Mar. Chem. 10: 467-473

Kirchman, D. L. (1994). The uptake of inorganic nutrients. Microb. Ecol. 28: 255-271

Kirchman, D. L., K'nees, E., Hodson, R. E. (1985). Leucine incorporation and its potential as a measure of protein synthesis by bacteria in natural aquatic systems. Appl. environ. Microbiol. 49: 599-607

Kjelleberg, S., Albertson, N., Flärdh, K., Holmquist, L., Jouper-Jaan, Å., Marouga, R., Östling, J., Svenblad, B., Weichart, D. (1993). How do non-differentiating bacteria adapt to starvation? Antonie van Leeuwenhoek 63: 333-341

Krom, M. D., Kress, N., Brenner, S., Gordon, L. I. (1991). Phosphorus limitation of primary production in the eastern Mediterranean. Limnol. Oceanogr. 36: 424-432

Laws, E. A., DiTullo, G. R, Redalje, D. G. (1987). High phytoplankton growth and production rates in the north Pacific subtropical gyre. Limnol. Oceanogr. 32: 905-918

Lindroth, P., Mopper, K. (1979). High performance liquid chromatographic determination of subpicomole amounts of amino acids by precolumn fluorescence derivatization with o-phthaldialdehyde. Analyt. Chem. 51: 1667-1674 
Logan, B. E., Fleury, R. C. (1993). Multiphasic kinetics can be an artifact of the assumption of saturable kinetics for microorganisms. Mar. Ecol. Prog. Ser. 102: 115-124

Miller, W. L. (1994). Recent advances in the photochemistry of natural dissolved organic matter. In: Helz, G. R., Zepp, R. G., Crosby, D. G. (eds.) Aquatic and surface photochemistry. Lewis Publishers, Boca Raton, p. 111-127

Moloney, C. L., Field, J. G. (1991). The size-based dynamics of plankton food webs. II. Simulating the standing stocks and size structure of three contrasting southern Benguela food webs. J. Plankton Res. 13: 1039-1092

Mopper, K., Lindroth, P. (1982). Diel and depth variations in dissolved free amino acids and ammonium in the Baltic Sea determined by shipboard HPLC analysis. Limnol. Oceanogr. 27: 336-347

Mopper, K., Zhou, X., Kieber, R. J., Kieber, D. J., Sikorski, R. J., Jones, R. D. (1991). Photochemical degradation of dissolved organic carbon and its impact on the oceanic carbon cycle. Nature 353: 60-62

Murphy, J., Riley, J. P. (1962). A modified single solution method for the determination of phosphate in natural waters. Analytica chim. Acta 27: 31-36

Nedwell, D. B., Rutter, M. (1994). Influence of temperature on growth rate and competition between two psychrotolerant Antarctic bacteria: low temperature diminishes affinity for substrate uptake. Appl. environ. Microbiol. 60: 1984-1992

Pace, M. L., Glasser, J. E., Pomeroy, L. R. (1984). A simulation analysis of continental shelf food webs. Mar. Biol. 82: 47-63

Pakulski, J. D., Benner, R., Amon, R., Eadie, B., Whitledge, T. (1995). Community metabolism and nutrient cycling in the Mississippi River plume: evidence for intense nitrification at intermediate salinities. Mar. Ecol. Prog. Ser. 117: 207-218

Peele, E. R., Ammerman, J. W., Bentzen, E., Cotner, J. B. Jr (1994). Microbial hydrolysis and utilization of dissolved organic phosphorus compounds at the Bermuda time-

This article was presented by S. Y. Newell (Senior Editorial Advisor), Sapelo Island, Georgia, USA series station. EOS 75: 76

Pomeroy, L. R., Sheldon, J. E., Sheldon, W. M. Jr (1994). Changes in bacterial numbers and leucine assimilation during estimations of microbial respiratory rates in seawater by the precision Winkler method. Appl. environ. Microbiol. 60: 328-332

Pomeroy, L. R., Wiebe, W. J. (1993). Energy sources for microbial food webs. Mar. microb. Food Webs 7: 101-118

Pomeroy, L. R., Wiebe, W. J., Deibel, D., Thompson, R. J., Rowe, G. T., Pakulski, J. D. (1991). Bacterial responses to temperature and substrate concentration during the Newfoundland spring bloom. Mar. Ecol. Prog. Ser. 75: 143-159

Simon, M., Azam, F. (1989). Protein content and protein synthesis rates of planktonic marine bacteria. Mar. Ecol. Prog. Ser. 51: 201-213

van Looij, A., Riemann, B. (1993). Measurements of bacterial production in coastal marine environments using leucine: application of a kinetic approach to correct for isotope dilution. Mar. Ecol. Prog. Ser. 102: 97-104

Vukovich, F. M. (1988). Loop current boundary variations. J. geophys. Res. 93C: 15585-15591

Walker, N. D., Kuh, O. K., Rouse, L. J. (1993). Warm-core eddy discovered in Gulf of Mexico. EOS 74: 338

Walsh, J. J., Dieterle, D. A., Meyers, M. B., Müller-Karger, F. E. (1989). Nitrogen exchange at the continental margin: a numerical study of the Gulf of Mexico. Prog. Oceanogr. 23: 245-301

Wheeler, P. A., Kirchman, D. L. (1986). Utilization of inorganic and organic nitrogen by bacteria in marine systems. Limnol. Oceanogr. 31: 998-1009

Wiebe, W. J., Sheldon, W. M. Jr, Pomeroy, L. R. (1993). Evidence for an enhanced substrate requirement by marine mesophilic bacterial isolates at minimal growth temperatures. Microb. Ecol. 25: 151-159

Wright, R. T., Hobbie, J. E. (1966). Use of glucose and acetate by bacteria and algae in aquatic ecosystems. Ecology 47 : 447-464

Manuscript first received: July 5, 1994

Revised version accepted: September 19, 1994 